\title{
Growth- and size-selective mortality in pelagic larvae of a common reef fish
}

\author{
S. Sponaugle ${ }^{1, *}$, J. N. Boulay ${ }^{2}$, T. L. Rankin ${ }^{3}$ \\ ${ }^{1}$ Marine Biology and Fisheries, Rosenstiel School of Marine and Atmospheric Science, University of Miami, \\ 4600 Rickenbacker Cswy., Miami, Florida 33149, USA \\ ${ }^{2}$ Present address: Department of Biology, The Pennsylvania State University, 213 Mueller Laboratory, University Park, \\ Pennsylvania 16802, USA \\ ${ }^{3}$ Present address: Office of Habitat Conservation, Habitat Protection Division, 1315 East-West Highway, SSMC3, \\ 14th Floor F/HC2, Silver Spring, Maryland 20910, USA
}

\begin{abstract}
Larvae of most aquatic species experience high mortality in the plankton and where traits are naturally variable, mortality can be selective. We tested the hypothesis that reef fish larvae with faster growth rates and larger size-at-age will be more likely to survive the pelagic larval period. We examined the otolith microstructure of larval bluehead wrasse Thalassoma bifasciatum collected across the Straits of Florida to obtain daily growth rates and relative size-at-age. Using a cross-sectional approach, we compared these traits between 2 larval age groups (young larvae: 18 to $26 \mathrm{~d}$ old, survivors: 27 to $36 \mathrm{~d}$ old) to determine whether mean traits varied with age. In contrast to expectations, survivors had slower early growth and were smaller-at-age than the young larvae, suggesting that faster growing, larger individuals were selectively removed from the population over time. To examine the role of water masses, we estimated maximum upstream larval positions. Differential current speeds across the Straits of Florida resulted in substantial overlap in back-estimated upstream locations of larvae at younger ages, suggesting that differences in early growth environments were unlikely the cause of the observed patterns. Instead, the most parsimonious explanation is the selective loss of fast-growing, large-at-age larvae in the plankton. Shifts in the direction of selective pressures across stages may contribute to the maintenance of high plasticity in the early life history traits of this species.
\end{abstract}

KEY WORDS: Larval growth $\cdot$ Straits of Florida $\cdot$ Growth-mortality hypothesis Resale or republication not permitted without written consent of the publisher

\section{INTRODUCTION}

Most marine organisms, including coral reef fishes, have a complex life cycle with a pelagic larval phase and a demersal (e.g. reef-associated) adult phase. Larval stages are typically subject to high mortality rates, and survival is often related to early life history traits such as fast growth and large size-at-age (Houde 1989, Meekan \& Fortier 1996, Hare \& Cowen 1997, Shoji \& Tanaka 2006, Takasuka et al. 2007). Larval traits can also influence recruitment success (Bergenius et al. 2002, Jenkins \& King 2006, Tanaka et al. 2006) and survival during the subsequent juvenile phase (Searcy \& Sponaugle 2001, Allain et al. 2003, McCormick \& Hoey 2004, Macpherson \& Raventos 2005, Sponaugle \& Grorud-Colvert 2006, Gagliano et al. 2007). Understanding survival during larval life is an essential component of quantifying larval transport, recruitment success, and connectivity of marine populations (Cowen \& Sponaugle 2009).

Early life history traits of larvae are also influenced by environmental conditions such as temperature (Houde 1989, Sponaugle et al. 2006), as well as by genetics and maternal effects (Berkeley et al. 2004, 
Planes \& Romans 2004). Traits such as growth and size-at-age are variable within and among cohorts of larvae and mortality can be selective with respect to these larval characteristics (Sogard 1997). The growth-mortality hypothesis (GMH) provides a theoretical framework for evaluating the importance of growth-related traits to larval survival. Based on the idea that most marine predators are gape-limited, the GMH predicts that mortality rates vary inversely with size and therefore larger individuals will have a lower probability of mortality, i.e. bigger-is-better hypothesis (Anderson 1988, Miller et al. 1988). Fastgrowing individuals are small and vulnerable for a shorter period of time (growth rate hypothesis), and those that spend less time in the plankton should have reduced exposure to high predation (stage duration hypothesis; Houde 1987, see Leggett \& DeBlois 1994 for review). Recent evidence has also demonstrated that some larvae experience growth-selective mortality, independent of size or stage duration (Takasuka et al. 2003).

While these hypotheses point to clear advantages of high growth rates and larger sizes-at-age, some argue that larger size confers higher vulnerability during pelagic life due to increased encounter rates by predators (Litvak \& Leggett 1992, Pepin et al. 1992, Bertram \& Leggett 1994, Leggett \& DeBlois 1994). Large size is not consistently superior when fish of the same age are compared (Litvak \& Leggett 1992, Bertram \& Leggett 1994).

Most studies of selective survival in the plankton have focused on temperate species; fewer have examined age-specific growth and survival in larvae of tropical species. The bluehead wrasse Thalassoma bifasciatum is a common western Atlantic/Caribbean reef fish that spawns daily (Warner \& Robertson 1978). Pelagic larvae spend a variable length of time (mean $\sim 50 \mathrm{~d}$ ) in the plankton prior to settling to the reef in pulses associated with the lunar cycle (Sponaugle \& Cowen 1997, Robertson et al. 1999). Larval growth varies directly with water temperature (Sponaugle et al. 2006) and prey availability (Sponaugle et al. 2009), with faster growers settling after shorter pelagic larval durations (PLD) and at smaller settlement sizes (Sponaugle et al. 2006). These relatively small, high-condition settlers on the reef have faster escape swimming speeds and spend less time in risk-taking behaviors (Grorud-Colvert \& Sponaugle 2006), with the result that survival of juveniles is significantly influenced by condition at the time of settlement (Searcy \& Sponaugle 2001, Sponaugle \& Grorud-Colvert 2006, Hamilton et al. 2008, Grorud-Colvert \& Sponaugle 2011). Ontoge- netic changes in relative growth and lipid storage at different stages in pelagic larvae therefore influence survival of settled fish (Hamilton et al. 2008). To further explore the linkages between larval and juvenile life, we tested the hypothesis that larvae in the plankton would experience selective mortality favoring larger, faster-growing individuals (according to the $\mathrm{GMH}$ ). Although most studies of selective mortality in fish larvae track and repeatedly sample a cohort over time (e.g. Meekan \& Fortier 1996, Hare \& Cowen 1997, Nielsen \& Munk 2004), we used repeated collections of larvae of different ages and followed a cross-sectional approach (Chambers \& Leggett 1987, Hawn et al. 2005). Recent comparisons of new settlers with surviving juveniles of another reef fish (the bicolor damselfish Stegastes partitus) have demonstrated that 2 approaches - tracking cohorts through time and integrative cross-sectional analyses - reveal similar patterns of selective mortality (Rankin 2010).

\section{MATERIALS AND METHODS}

\section{Field collection}

As part of a larger study focused on larval billfishes, ichthyoplankton samples were collected at 17 stations on an east-west transect across the Straits of Florida from Miami, Florida, to Bimini, Bahamas $\left(25.5^{\circ} \mathrm{N}_{i}\right.$ Fig. 1). Stations were spaced $\sim 2 \mathrm{~km}$ apart at the 3 western- and easternmost stations and $\sim 5.5 \mathrm{~km}$ apart at the central stations. A modified Multiple Opening and Closing Net and Environmental Sampling System (MOCNESS) was used to sample the water column during daylight hours over $2 \mathrm{~d}$ at the beginning of each month of 2003 and 2004. The MOCNESS is a combination of 2 sets of nets with different opening and mesh sizes $\left(4 \mathrm{~m}^{2}, 1 \mathrm{~mm}\right.$ mesh; $1 \mathrm{~m}^{2}, 150 \mu \mathrm{m}$ mesh) that can simultaneously collect fish larvae and their potential prey at discrete depth intervals of $25 \mathrm{~m}$ from 1 to $100 \mathrm{~m}$ (Guigand et al. 2005). To sample the sea surface to $\sim 0.5 \mathrm{~m}$ depth, adjoined neuston nets $(2 \times 1 \mathrm{~m}, 1 \mathrm{~mm}$ mesh; $0.5 \times 1 \mathrm{~m}$, $150 \mu \mathrm{m}$ mesh) were deployed. The MOCNESS also collected hydrographic data and provided an estimate of the volume of water filtered during each collection. Plankton samples were fixed in $95 \%$ ethanol and stored in $70 \%$ ethanol. All larval fishes were separated from the samples and identified to the lowest possible taxonomic category using standard identification guides (Richards 2005). Thalassoma bifasciatum larvae are easily identified by their distinct shape and pigmentation. 


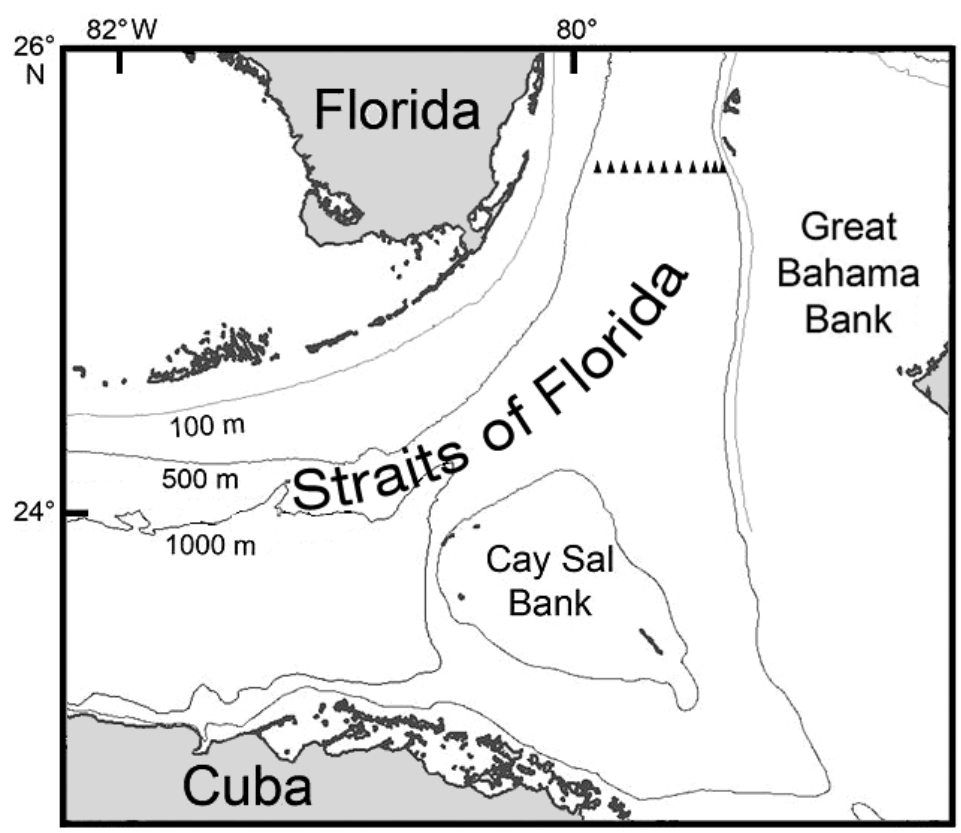

Fig. 1. Study area with the 11 sampling stations (triangles) used in the present study. For the location of all 17 stations, refer to Sponaugle et al. (2009)

\section{Samples}

In total, 1049 larval Thalassoma bifasciatum were collected during the 8 cruises in July to October 2003 and 2004 (for year-round station-specific abundances see Sponaugle et al. 2009, their Fig. 2). Collections from these months were chosen for the present analysis to minimize temperature variability, which significantly influences larval growth rates in T. bifasciatum (Sponaugle et al. 2006). Larvae collected from the 6 westernmost stations (Stns 0 to 5) were also excluded, because they have higher growth rates than larvae from the central and eastern stations (Sponaugle et al. 2009). Most larvae occurred in the 0 to $25 \mathrm{~m}$ depth bin; to reduce potential depth effects, we excluded larvae collected from $>50 \mathrm{~m}$ depth. For each larva, standard length (SL) was measured to the nearest $0.1 \mathrm{~mm}$ using a Leica MZ12 dissecting microscope attached to a Dage MTI video camera and Image Pro-Plus 4.5 image analysis software (Media Cybernetics). After measurement, larvae were binned into $1 \mathrm{~mm} \mathrm{SL}$ categories for each year. There were sufficient numbers of larvae for analysis in the SL categories between 3.0 and $8.0 \mathrm{~mm}$, so 25 larvae were randomly selected from each length category in each year, with the exception of the 7.0 to $8.0 \mathrm{~mm}$ length category in 2004, where there were only 23 larvae.

\section{Otolith analysis}

Growth and size data were obtained through the analysis of otoliths. Increments are deposited daily in the otoliths of Thalassoma bifasciatum (Victor 1982), and there is typically a significant positive relationship between otolith size and SL, as well as the residuals of each (e.g. for Florida Straits T. bifasciatum larvae: Sponaugle et al. 2009). Thus, the number of increments in an otolith not only provides a measure of larval age, but otolith radius at a given increment is an indication of size-at-age. The width between successive otolith increments is a proxy for daily somatic growth (Searcy \& Sponaugle 2001). Therefore, for each larva we had a measure of size and age, as well as hindcast sizes and growth at particular points earlier in its life.

We followed a standard protocol to prepare the otoliths of the 248 larvae selected for analysis (see Sponaugle et al. 2006, 2009). Both pairs of lapillar and sagittal otoliths were dissected out of each larva and placed on a microscope slide in a drop of medium viscosity immersion oil. After a period of 7 to $24 \mathrm{~d}$ (to allow otolith features to become more visible), the sagittal otoliths were read at $1000 \times$ oil-immersion magnification along the longest axis of the clearer otolith using a Leica DMLB microscope equipped with a polarized filter between the first stage and light source. As with the fish measurements, a Dage MTI video camera attached to the microscope was used to transmit images to a computer equipped with Image Pro-Plus $4.5 \mathrm{im}$ age analysis software (Media Cybernetics), where images were sharpened and analyzed. The position of each increment on each otolith was identified using the sharpened images and direct view through the microscope. Each otolith was read twice by a single reader lacking size or age information. If the difference between the 2 readings was $\geq 5 \%$, the otolith was read a third time, and if the discrepancy in age remained $\geq 5 \%$, the otolith was discarded. If the age difference between the 2 readings was $<5 \%$, one of the 2 readings was randomly selected for analysis. In total, 23 individuals were excluded, resulting in 225 individuals between 12 and $42 \mathrm{~d}$ of age, which were fairly evenly distributed across the cruises (i.e. each cruise had a

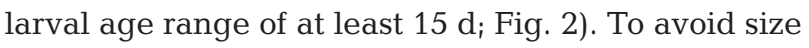
bias, as the smallest larvae may not be well represented in the samples (i.e. extruded through the $1 \mathrm{~mm}$ mesh) and the largest larvae may be able to evade nets, we excluded all larvae $\leq 4 \mathrm{~mm}$ and $<18 \mathrm{~d}$ old and those $>36 \mathrm{~d}$ old, leaving a total of 188 larvae. 


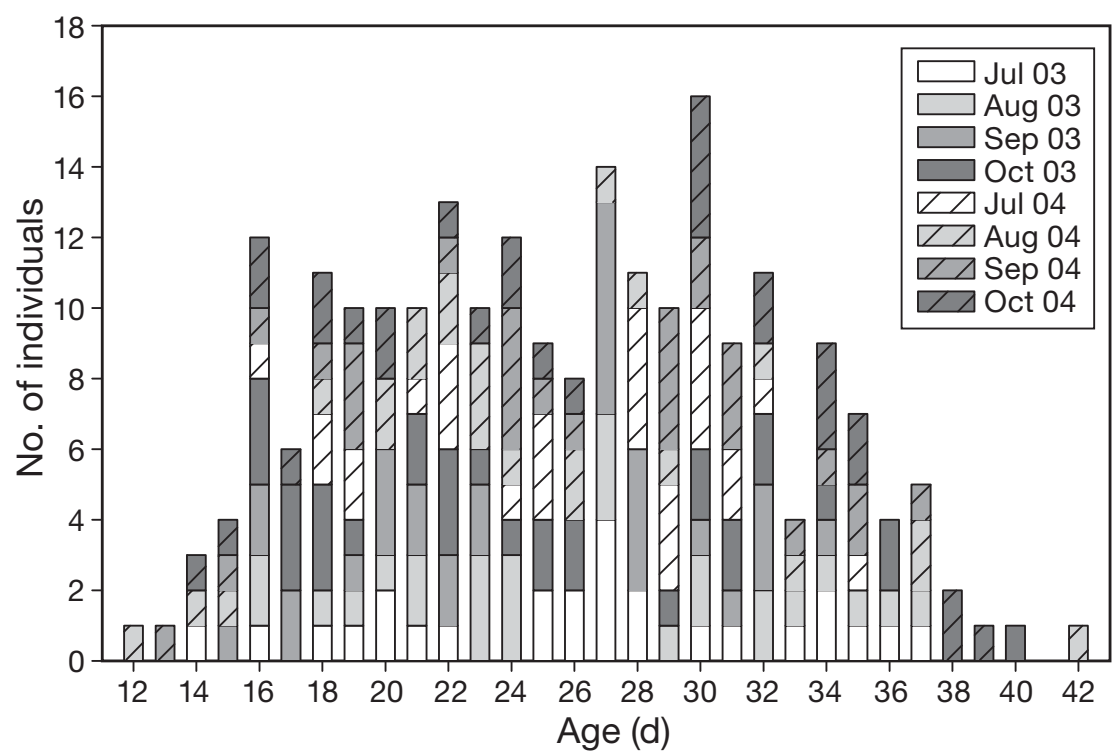

Fig. 2. Thalassoma bifasciatum. Distribution of ages of larvae collected in the Straits of Florida during 8 cruises in 2003 and 2004

\section{Data analysis and upstream distance computations}

Based on sample sizes, aged larvae were divided into 2 age groups: 'young fish' (18 to $26 \mathrm{~d}$ old) and 'survivors' (27 to $36 \mathrm{~d}$ old). Our goal was to compare mean traits (i.e. growth and size-at-age) at 2 points (Days 10 and 15, i.e. otolith increment 10 and 15, respectively) between the 2 age groups to determine whether survivors exhibited faster growth and/or larger sizes at each point than the younger group as a result of the selective loss of slower-growing, smaller larvae. Before combining samples, we used ANOVA (SYSTAT version 11) to test that growth and size-at-age were similar across months within each age group. We first accounted for variation in water temperature by regressing each trait against water temperature and testing the residuals of the relationships. At least 1 trait differed in one age group in 3 of the months (ANOVA for July 2003, 2004, August 2004: p < 0.05); for the primary analysis, we therefore used larvae from the remaining 5 months (August 2003, September 2003, October 2003, September 2004, October 2004), in which growth and size-at-age did not differ from one another (Table 1). The final $t$-tests compared each trait (residuals of traits regressed against temperature as above) between 58 young larvae and 62 survivors. To further illustrate the relationships between early life history traits and larval age, we tested mean growth (over Days [otolith increments] 6 to 10 and 11 to 15) and size-at-age (Days [increment] 10 and 15) against larval age for all individuals using Spearman's coefficient of rank correlation (Hawn et al. 2005).
All larvae analyzed were collected along a single transect; thus, older larvae were likely in a different location at specific points earlier in larval life relative to younger larvae. Biophysical modeling was beyond the scope of the study, so to roughly estimate maximum potential distances from the transect at which larvae may have been located at each of 2 age periods (i.e. when each fish was 6 to $10 \mathrm{~d}$ old and 11 to $15 \mathrm{~d}$ old), we used the current speeds recorded at each station and hindcast upstream distances based on larval ages. For the purpose of these calculations, it was assumed that current speeds were constant upstream and that larvae moved passively with the currents (which becomes increasingly less realistic as larvae age). Approximate distances from the transect were calculated for each individual; note that these do not reflect real upstream sources. These basic calculations were not intended to reflect realized larval transport, but were used to illustrate potential maximum differences in location during periods of interest among larvae of different ages.

\section{RESULTS}

\section{Size distributions}

Thalassoma bifasciatum larvae collected from July to October in 2003 and 2004 ranged between 2.0 and $12.0 \mathrm{~mm}$ SL, with roughly similar size distributions

Table 1. ANOVA on otolith-derived, early life history traits of Thalassoma bifasciatum larvae collected over 5 sampling months: August 2003, September 2003, October 2003, September 2004, October 2004. Traits were regressed against water temperature and the residuals used to compare traits within 2 age groups (young: 18 to $26 \mathrm{~d}$ old; survivors: 27 to 36 d old)

\begin{tabular}{|llcc|}
\hline \multirow{2}{*}{ Age group } & Trait & Days post-hatch & $\mathrm{p}$ \\
\hline Young & Mean growth & 6 to 10 & 0.770 \\
& (otolith increment width) & 11 to 15 & 0.237 \\
& Mean size-at-age & 10 & 0.329 \\
\multirow{5}{*}{ Survivors } & (otolith radius) & 15 & 0.592 \\
& Mean growth & 6 to 10 & 0.290 \\
& (otolith increment width) & 11 to 15 & 0.111 \\
& Mean size-at-age & 10 & 0.326 \\
& (otolith radius) & 15 & 0.157 \\
\hline
\end{tabular}


among the different cruises (larvae collected in July of each year had a somewhat narrower size range of 3.0 to 8.0 or $9.0 \mathrm{~mm}$; Fig. 3). Larvae $<2.0 \mathrm{~mm}$ SL were not captured, because $T$. bifasciatum hatch at about $1.4 \mathrm{~mm}$ (Holt 2003) and very small larvae can pass through the $1 \mathrm{~mm}$ mesh of the MOCNESS. The decline in the number of larvae with increasing size reflects the high mortality experienced by larval fishes. Further, larvae settle to the reef at $\sim 10 \mathrm{~mm} \mathrm{SL}$ (Sponaugle \& Cowen 1997) and may be able to evade nets at the very largest sizes. Note that the smallest and largest larvae included in these plots were excluded from data analysis.

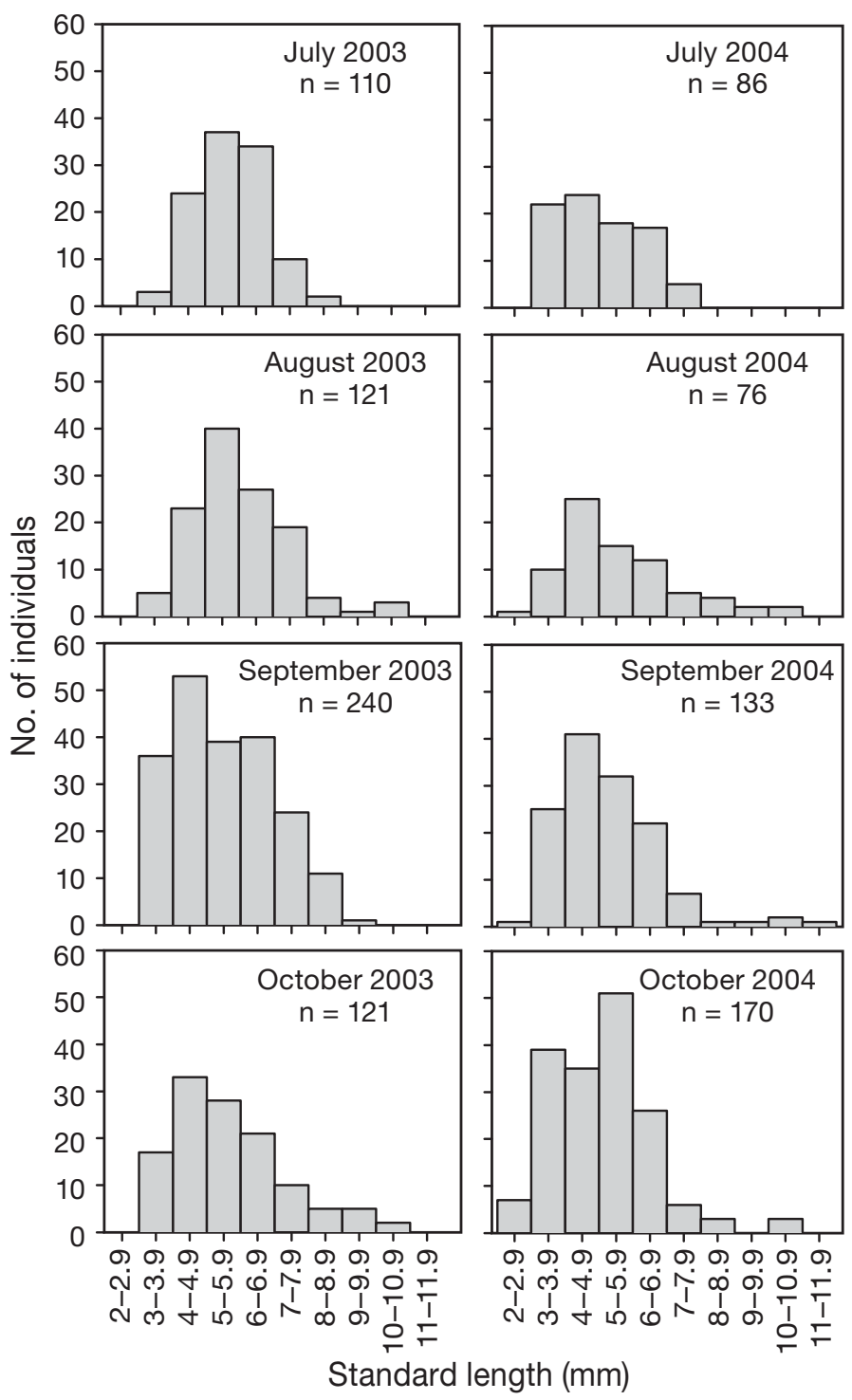

Fig. 3. Thalassoma bifasciatum. Standard length of all larvae collected during 8 cruises in the Straits of Florida; the smallest and largest larvae in these plots were excluded from analysis of selective mortality

\section{Selective mortality}

By Days 6 to 10, young Thalassoma bifasciatum larvae (18 to $26 \mathrm{~d}$ old) had faster mean growth rates and were larger-at-age than older surviving larvae (27 to $36 \mathrm{~d}$ old; $t$-test: $\mathrm{p}=0.011$; Table 2, Fig. 4). Growth differences led to significantly larger sizes-at-age of the young larvae compared to the survivors beginning at Day 10 ( $t$-test: $p=0.014)$. As the fish aged, differences between the 2 groups became more distinct (Table 2) - the same significant patterns were evident if larvae from all months were used in the analyses: $\mathrm{n}=93$ young larvae, 95 survivors $(t$-test: $\mathrm{p}=$ $<0.001$ to 0.009 ; growth and size of young larvae $>$ survivors). This pattern of survivors exhibiting slower growth and smaller sizes at early ages than young larvae is further apparent when examining individual traits by age: mean growth and size-at-age decreased significantly with increasing age $\left(\mathrm{r}_{\mathrm{s}}=-0.29\right.$ to $-0.41 ; \mathrm{p}<0.01$ to 0.001 ; Fig. 5).

\section{Upstream larval positions}

Currents measured along the transect were consistently dominated by northward flow, which was stronger on the western side of the transect, reflecting the dominant Florida Current (Fig. 6). As a result, rough approximations of the upstream locations of larvae illustrate that there was a greater spread between the 2 age groups in the potential locations of larvae at earlier periods for larvae collected from the western portion of the transect (Stns 6 to 11; maximum of $\sim 1000$ to $2000 \mathrm{~km}$ difference between age groups; Fig. 7). The distributions of larvae collected from the eastern stations (Stns 12 to 16) more frequently overlapped (maximum of $<500 \mathrm{~km}$ difference between age groups). No age group of larvae was confined to a distinct region.

Table 2. Student's $t$-test of growth (otolith increment width) and size-at-age (otolith radius at age) between 2 age groups ( $\mathrm{Y}=$ young larvae; 18 to $26 \mathrm{~d}$ old; $\mathrm{S}=$ survivors: 27 to $36 \mathrm{~d}$ old) of Thalassoma bifasciatum from the Straits of Florida. To account for the potential influence of water temperature, traits were regressed against water temperature and the residuals used in each analysis

\begin{tabular}{|lccc|}
\hline Trait & Days post-hatch & $\mathrm{p}$ & \\
\hline Mean growth & 6 to 10 & 0.011 & $\mathrm{Y}>\mathrm{S}$ \\
(increment width) & 11 to 15 & 0.001 & $\mathrm{Y}>\mathrm{S}$ \\
Mean size-at-age & 10 & 0.014 & $\mathrm{Y}>\mathrm{S}$ \\
(otolith radius) & 15 & 0.001 & $\mathrm{Y}>\mathrm{S}$ \\
\hline
\end{tabular}




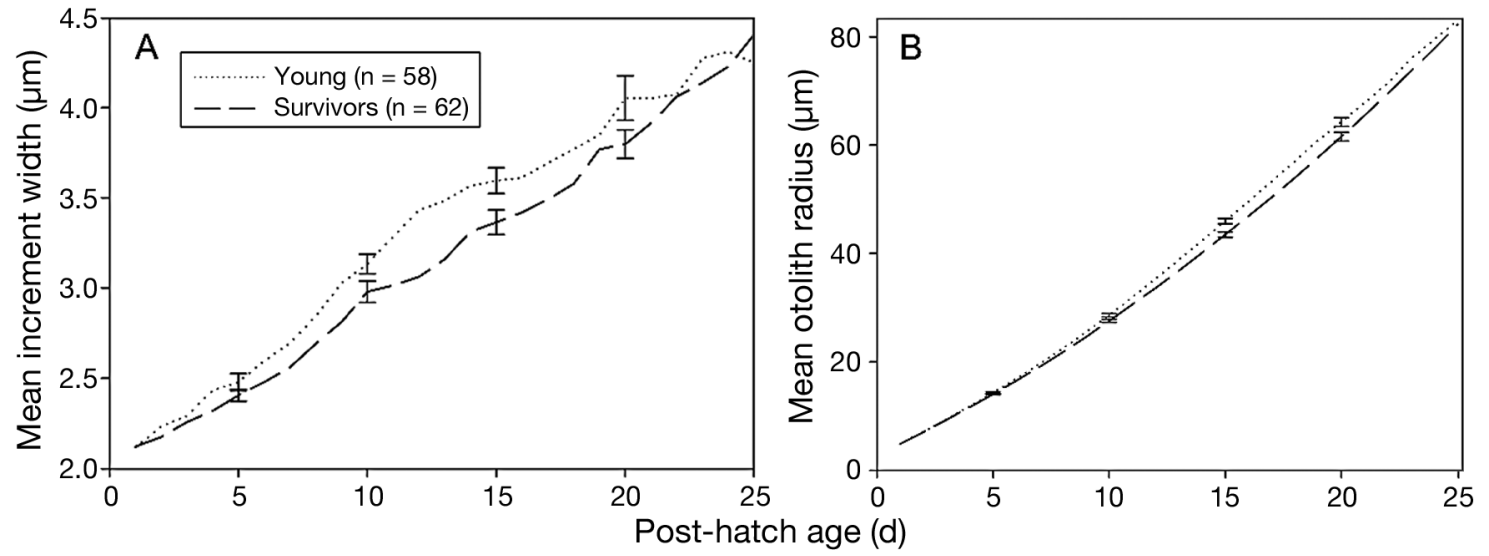

Fig. 4. Thalassoma bifasciatum. (A) Mean daily growth (otolith increment width) and (B) mean size-at-age (otolith radius at age) at each day of life for 2 larval age groups. Data plotted to minimum age of each group; error bars included every $5 \mathrm{~d}$ for reference

\section{DISCUSSION}

In contrast to expectations, larvae of Thalassoma bifasciatum experience pelagic mortality that appears to select against fast-growing, large-at-age individuals. Using a cross-sectional approach whereby larvae collected over 5 separate months were grouped by age, we found that older, surviving larvae had significantly slower growth throughout early larval life, resulting in smaller sizes-at-age than younger fish.

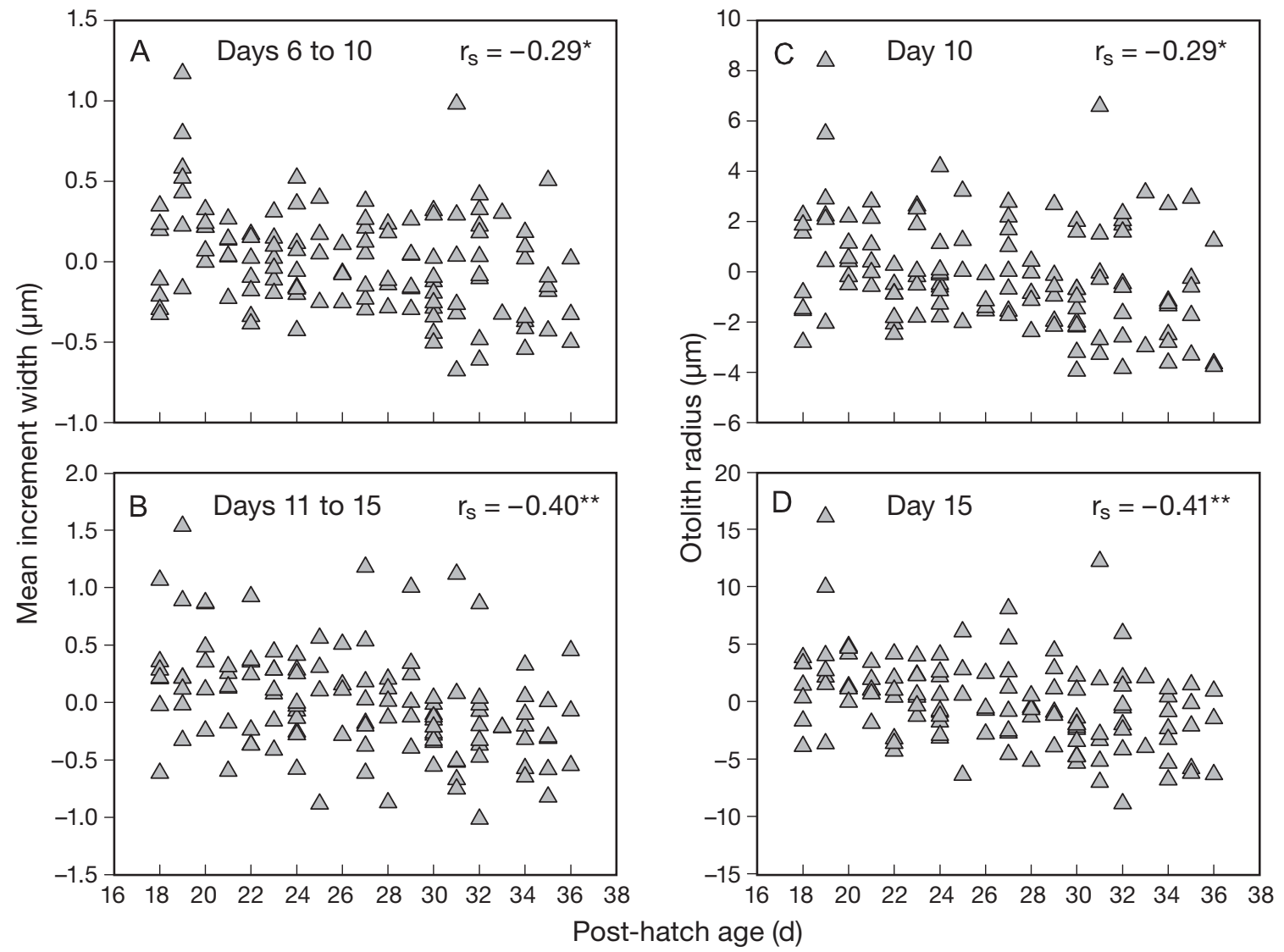

Fig. 5. Thalassoma bifasciatum. Relationship between $(\mathrm{A}, \mathrm{B})$ mean daily growth (otolith increment width) and age, and $(\mathrm{C}, \mathrm{D})$ size-at-age (otolith radius) and age for larvae collected in the Straits of Florida. Traits at particular time periods (Days 6 to 10 and Days 11 to 15 for growth; Days 10 and 15 for size-at-age) were regressed against water temperature and the residuals used in the analysis. Spearman rank correlation $\left(\mathrm{r}_{\mathrm{s}}\right)$ for each plot was significant at ${ }^{*} \mathrm{p}<0.01,{ }^{* *} \mathrm{p}<0.001$ 


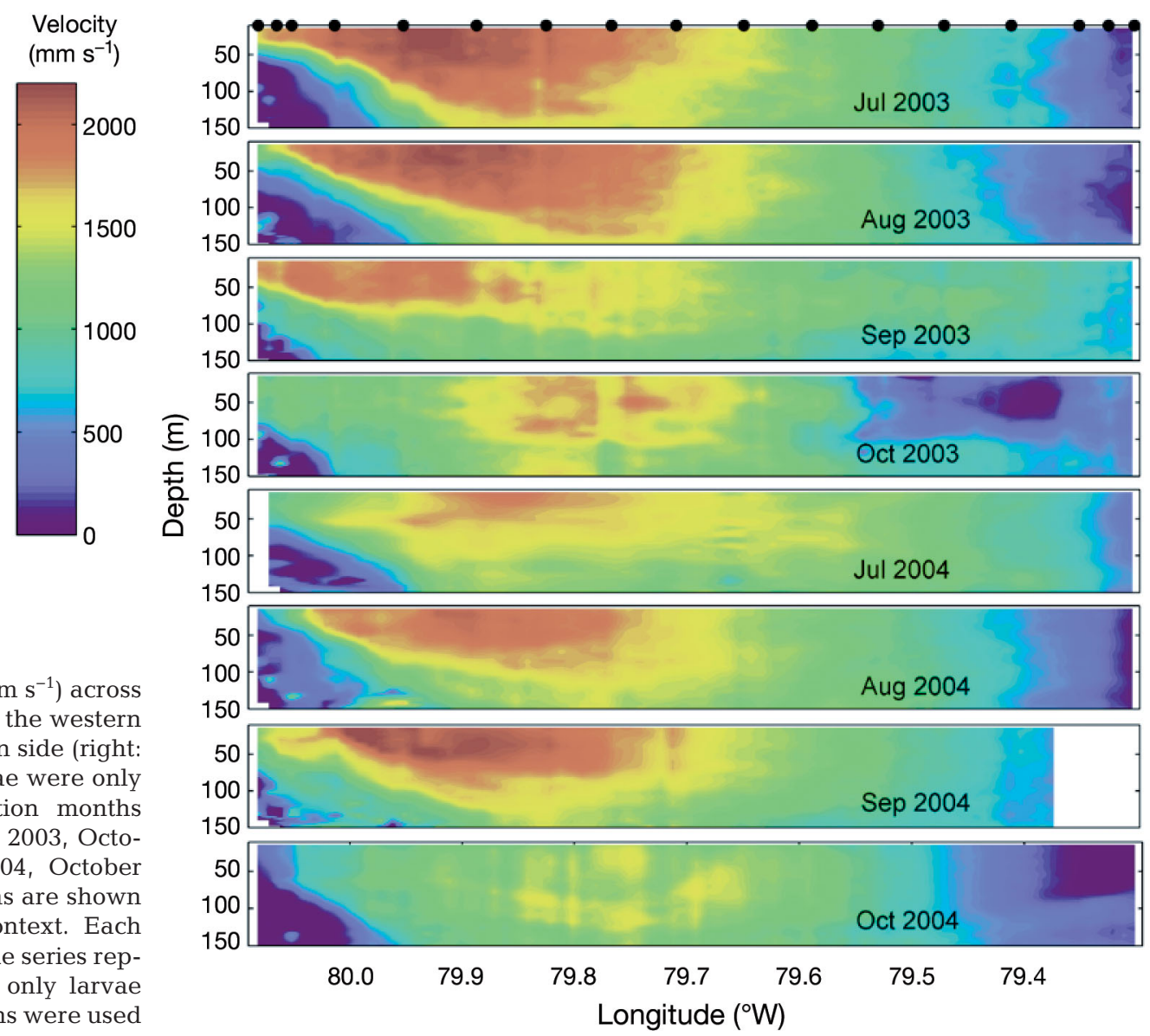

Fig. 6. Current speeds $\left(\mathrm{mm} \mathrm{s}^{-1}\right)$ across the Straits of Florida from the western (left: Miami) to the eastern side (right Bahamas). Although larvae were only analyzed from 5 collection month (August 2003, September 2003, October 2003, September 2004, October 2004), all sampling months are shown to provide a broader context. Each black point at the top of the series represents 1 of 17 stations; only larvae from the eastern 11 stations were used

This surprising finding is opposite to predictions of the $\mathrm{GMH}$, which states that faster growing, largerat-age fish should have a higher probability of survival. Although particular cohorts of larvae were not tracked and repeatedly sampled over time, larvae of both age groups were collected every month and ages were evenly spread over the different cruises. Further, we excluded the smallest and largest larvae that may not have been adequately sampled, used larvae only from the upper water column, and accounted for small variations in water temperature. Rough hindcast positions of larvae indicate that young and old larvae collected from western stations were potentially positioned at different upstream locations during early life, but those from eastern stations frequently overlapped. As larvae from all stations were combined in the analysis, it is unlikely that observed growth patterns were due to different ages occupying different upstream water masses. While we cannot entirely exclude the effects of spatial and temporal aliasing, the most parsimonious interpretation of the data is that fast-growing, largeat-age larvae are at a selective disadvantage in the plankton.

\section{Selective mortality}

Size-related traits

Although the cumulative benefits of large size (lower vulnerability to gape-limited predators) and fast growth (shorter period of exposure to predation) should lead to significantly higher survival to metamorphosis for faster-growing larvae (Anderson 1988, Bertram \& Leggett 1994), the situation may be reversed from the predators' perspective. The act of predation consists of 3 separate components: detection/encounter, attack, and capture; vulnerability of a larva to mortality by predation is a function of the probability of each of these events (Litvak \& Leggett 1992). Larger and more active larvae may be more vulnerable to predation than smaller, less active larvae, due to higher detection rates by predators (Ibrahim \& Huntingford 1989). Larger larvae are not only more frequently encountered but are also more favorable as prey (larger mass) (optimal foraging theory: MacArthur \& Pianka 1966); however, their capture may be more difficult. Experimental predation studies indicate that larger larvae have a higher 

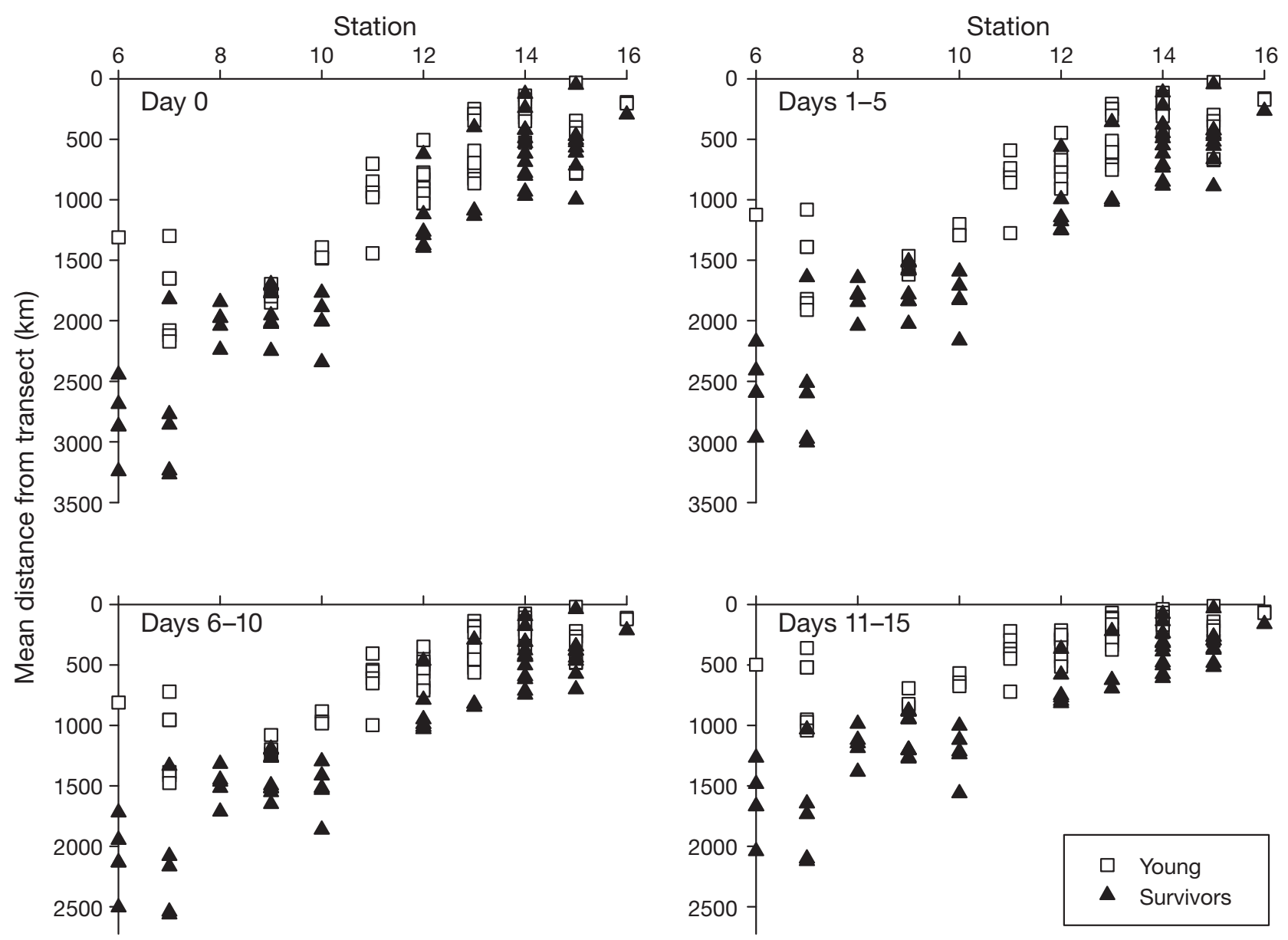

Fig. 7. Distance from the sampling transect (according to station) at which Thalassoma bifasciatum larvae in 2 age groups (young: 18 to $26 \mathrm{~d}$ old; survivors: 27 to $36 \mathrm{~d}$ old) are calculated to have hatched (Day 0), or been present at during Days 1 to 5, 6 to 10 , and 11 to 15 if subjected to the current speeds measured along the transect throughout the period. Stations are not positioned to scale with respect to longitude. Distances from the transect are maximum estimates, as current speeds are not constant over such distances; larval behavior was not considered

probability of escaping an attack (Folkvord \& Hunter 1986, Litvak \& Leggett 1992). Microcosm experiments in which larvae of similar ages but different sizes were exposed to visual and non-visual predators demonstrated that smaller larvae had a survival advantage because the probability of encounter and attack on larger larvae exceeded the decline in the probability of their capture (Litvak \& Leggett 1992).

The ratio of prey to predator size is an important determinant of prey vulnerability (Bailey \& Houde 1989) and potential selective mortality. Prey are most vulnerable when they are $\sim 10 \%$ of the length of predators (Paradis et al. 1996). Below this size, increasing prey size leads to increased vulnerability, whereas above this size increasing prey size enhances the size refuge (Pepin et al. 1992). Thus, the degree to which larger or smaller prey are selected by a predator will depend on relative prey and predator sizes and this is expected to change with ontogeny and predator type (Pepin et al. 1992). Predator type influences the degree to which predation is selective for certain prey traits of larval (Takasuka et al. 2004, 2007, Robert et al. 2010) and juvenile fishes (McCormick \& Hoey 2004).

\section{Growth-related traits}

Growth and size-at-age are inherently linked and it can be challenging to disentangle the relative importance of the 2 variables to survival. Variation in relative growth frequently leads to differences in size-at-age, which, as detailed above, can substantially influence survival (GMH). However, relative growth may also influence larval survivorship independently from size through differences in prey 
behavior and vulnerability (growth-selective mortality: Takasuka et al. 2003). We have no evidence of the independent importance of growth to survival; however, it is possible that preferential survival of Thalassoma bifasciatum during the first few weeks of larval life may have been due primarily to slower growth rates. While fast-growing larvae usually experience enhanced survival (Takasuka et al. 2003, 2004), this is not always the case (Takasuka et al. 2007, Robert et al. 2010), and under some conditions, survival advantages are associated with slowergrowing individuals (Leggett \& DeBlois 1994). Rapid growth can result in poor or weakened development, tissue maintenance and swimming capabilities (Arendt 1997). In addition to direct effects on larvae within the plankton, costs may extend to settlement and benthic juvenile life. Fast growth may lead to metamorphosis at a young age at the expense of the development of neuromuscular tissues (Billerbeck et al. 2001) and other systems associated with predator detection and avoidance (Bertram \& Leggett 1994). Slow growers typically have longer PLDs, and thus larger sizes at settlement (Sponaugle et al. 2006), which can be a survival advantage for young juveniles (Gagliano \& McCormick 2007, Johnson \& Hixon 2010). However, for T. bifasciatum, survival of young recruits is highest for those that settle at smaller sizes after a short PLD (Sponaugle \& Grorud-Colvert 2006, Grorud-Colvert \& Sponaugle 2006). The accumulation of lipids during larval life is related to growth, and condition (lipid content) at the time of settlement directly influences early juvenile survival in T. bifasciatum (Searcy \& Sponaugle 2001, Hamilton 2008). Hamilton et al. (2008) found that $T$. bifasicatum settling to St. Croix followed one of 2 growth scenarios: (1) early slow growth followed by faster growth and higher settlement condition, or (2) fast early growth followed by slower growth and low settlement condition; the former group experienced higher juvenile survival rates. Thus, initially slow-growing larvae may be able to switch to faster growth later and experience higher post-settlement survival (Hamilton et al. 2008).

\section{Differential growth environments}

While selection against fast growers is a likely explanation for the observed patterns of larval growth, the possibility that larvae experienced different growth environments cannot be excluded. Reef fish recruits exhibiting contrasting larval growth histories can have occupied different coastal water masses as larvae (Sponaugle \& Pinkard 2004, Hamilton et al. 2008, Shima \& Swearer 2010). Due to the nature of our sampling along a single transect, older larvae ('survivors') were likely spawned farther upstream and could have spent a considerable amount of time in a different water mass than younger larvae. Therefore, it is possible that differences in growth and size among age groups were due to a difference in the early growth environments and not the higher vulnerability of faster growers. To examine this and determine whether larvae of different ages occurred in specific water masses, we computed potential distances from the transect for earlier points in the life of the larvae. Larvae from the easternmost stations (Stns 12 to 16) had overlapping distributions, while faster current speeds at the western stations (Stns 6 to 11 ) resulted in larvae being farther apart at a given age. Note that the use of mean currents likely overestimated these upstream distances, thus this rough computation should be considered an extreme, or 'worst-case' scenario. At all previous ages, larvae from the western stations were farther upstream than larvae from eastern stations. Thus, all larvae from a given age group were not sourced from a single upstream location or region, and larvae from all stations were combined in the analysis. Therefore, evidence is consistent with the most parsimonious interpretation of generally selective loss of faster growing/ larger-at-age individuals.

\section{Selective mortality and plasticity in early life history}

We found selection against fast growth in larval Thalassoma bifasciatum for the first half of the larval period. Differences in otolith-derived traits between young and surviving larvae appear to continue to Day 30, but we have no data on patterns beyond this point. Differences in the growth trajectories may converge and even reverse as time goes on because selective processes in early life can disappear or switch direction ontogenetically (Meekan et al. 2006, Gagliano et al. 2007, Johnson \& Hixon 2010). Thalassoma bifasciatum has a variable early life history, exhibiting a wide range of larval growth rates and PLDs (Sponaugle et al. 2006, Sponaugle \& GrorudColvert 2006). Selective processes in early juvenile life favor high condition individuals that settle at small sizes after relatively short PLDs (GrorudColvert \& Sponaugle 2011). Because PLD is inversely related to larval growth (Searcy \& Sponaugle 2000, Sponaugle et al. 2006), survivors in the plankton 
(slow-growers) may be at a disadvantage postsettlement (long PLD, low condition). However, as previously noted, early slow growers can also switch and exhibit faster growth later in larval life, leading to higher condition at settlement (Hamilton et al. 2008). Conflicting selection pressures within and between life stages may contribute to the finding that among $T$. bifasciatum juveniles, survival is not significantly related to larval growth (Searcy \& Sponaugle 2001, Grorud-Colvert \& Sponaugle 2011). Strong early selective mortality tends to reduce variation in particular traits, making additional selective mortality on later stages less likely or detectable (Sogard 1997), however, ontogentic changes in the direction of selection promote phenotypic plasticity (Swain 1992). Shifts in the direction of trait-mediated survival between larval life and post-settlement juveniles may underlie the high plasticity in early life history traits in this species.

In summary, our results indicate that mortality of T. bifasciatum larvae in the plankton is selective against fast growers during early larval life. The existence and direction of selective processes will affect the characteristics of larvae that survive to settle and metamorphose into juveniles. However, once settled onto the reef, juveniles may experience opposing selective pressures that select for individuals with a different suite of traits. The degree to which mortality is selective depends not only on life stage (Gagliano et al. 2007, Johnson \& Hixon 2010), variation in prey traits (Sogard 1997), and prey availability (Shoji \& Tanaka 2006, Robert et al. 2007), but also on their environment (Grorud-Colvert \& Sponaugle 2011, Rankin \& Sponaugle 2011), and the specific characteristics of the predators (Takasuka et al. 2007, Robert et al. 2010). For organisms with complex life cycles, ontogenetic and environment-induced changes in selection pressure can complicate survivor life history strategies.

Acknowledgements. This project was supported in part by the National Science Foundation under grants no. 0136132 and 0550732. R.K. Cowen, D. Richardson, J. Llopiz, C. Guigand, P. Lane, A. Shiroza, K. Leaman, P. Vertes, and S. Smith participated in shipboard cruises. All samples were collected under the UM ACUC permits \#02063 and 05134. Sample sorting was conducted by L. Gundlach, A. Exum, and S. Trbovich, and larvae were identified by J. Llopiz and D. Richardson. Additional thanks to J. Llopiz for help with statistical analyses and preparation of Figs. $1 \& 6$, and to E. D'Alessandro and 3 reviewers who provided comments on an early draft. Any opinions, findings, conclusion, or recommendations expressed in this material are those of the authors and do not necessarily reflect the views of the National Science Foundation.

\section{LITERATURE CITED}

Allain G, Petigas P, Grellier P, Lazure P (2003) The selection process from larval toe juvenile stages of anchovy (Engraulis encrasicolus) in the Bay of Biscaye investigated by Langrangian simulations and comparative otolith growth. Fish Oceanogr 12:407-418

Anderson JT (1988) A review of size dependent survival during pre-recruit stages of fishes in relation to recruitment. J Northwest Atl Fish Sci 8:55-66

Arendt JD (1997) Adaptive intrinsic growth rates: An integration across taxa. Q Rev Biol 72:149-177

Bailey KM, Houde ED (1989) Predation on eggs and larvae of marine fishes and the recruitment problem. Adv Mar Biol 25:1-83

> Bergenius MAJ, Meekan MG, Robertson DR, McCormick MI (2002) Larval growth predicts the recruitment success of a coral reef fish. Oecologia 131:521-525

Berkeley SA, Chapman C, Sogard SM (2004) Maternal age as a determinant of larval growth and survival in a marine fish, Sebastes melanops. Ecology 85:1258-1264

Bertram DF, Leggett WC (1994) Predation risk during the early life history periods of fishes: separating the effects of size and age. Mar Ecol Prog Ser 109:105-114

$>$ Billerbeck JM, Lankford TE, Conover DO (2001) Evolution of intrinsic growth and energy acquisition rates. I. Tradeoffs with swimming performance in Menidia menidia. Evolution 55:1863-1872

Chambers RC, Leggett WC (1987) Size and age at metamorphosis in marine fishes: an analysis of laboratory reared winter flounder (Pseudopleuronectes americanus) with a review of variation in other species. Can J Fish Aquat Sci 44:1936-1947

> Cowen RK, Sponaugle S (2009) Larval dispersal and marine population connectivity. Annu Rev Mar Sci 1:443-466

Folkvord A, Hunter JA (1986) Size-specific vulnerability of northern anchovy, Engraulis mordax, larvae to predation by fishes. Fish Bull 84:859-870

Gagliano M, McCormick MI (2007) Compensating in the wild: Is flexible growth the key to early juvenile survival? Oikos 116:111-120

Gagliano M, McCormick MI, Meekan MG (2007) Survival against the odds: ontogenetic changes in selective pressure mediate growth-mortality trade-offs in a marine fish. Proc Biol Sci 274:1575-1582

Grorud-Colvert K, Sponaugle S (2006) Influence of condition on behavior and survival potential of a newly settled coral reef fish, the bluehead wrasse Thalassoma bifasciatum. Mar Ecol Prog Ser 327:279-288

Grorud-Colvert K, Sponaugle S (2011) Variability in temperature affects trait-mediated survival a newly settled coral reef fish. Oecologia 165:675-686

Guigand CM, Cowen RK, Llopiz JK, Richardson DE (2005) A coupled asymmetrical multiple opening closing net with environmental sampling system. Mar Technol Soc J 39: $22-24$

Hamilton SL (2008) Larval history influences post-metamorphic condition in a coral-reef fish. Oecologia 158:449-461

> Hamilton SL, Regetz J, Warner RR (2008) Postsettlement survival linked to larval life in a marine fish. Proc Natl Acad Sci USA 105:1561-1566

Hare JA, Cowen RK (1997) Size, growth, development, and survival of the planktonic larvae of Pomatomus saltatrix (Pisces: Pomatomidae). Ecology 78:2415-2431

Hawn AT, Martin GB, Sandin SA, Hare JA (2005) Early juvenile mortality in the coral reef fish Chromis cyanea (Pomacentridae): the growth-mortality hypothesis revis- 
ited. Bull Mar Sci 77:309-318

Holt GJ (2003) Research on culturing the early life history stages of marine ornamental species. In: Cato JC, Brown CL (eds) Marine ornamental species: collection, culture and conservation. Iowa State Press, Ames, IO

Houde ED (1987) Fish early life dynamics and recruitment variability. Am Fish Soc Symp 2:17-29

Houde ED (1989) Comparative growth, mortality, and energetics of marine fish larvae-temperature and implied latitudinal effects. Fish Bull 87:471-495

Ibrahim AA, Huntingford FA (1989) The role of visual cues in prey selection in 3-spined sticklebacks (Gasterosteus aculeatus). Ethology 81:265-272

> Jenkins GP, King D (2006) Variation in larval growth can predict the recruitment of a temperate, seagrass-associated fish. Oecologia 147:641-649

Johnson DW, Hixon MA (2010) Ontogenetic and spatial variation in size-selective mortality of a marine fish. J Evol Biol 23:724-737

Leggett WC, DeBlois E (1994) Recruitment in marine fishes: is it regulated by starvation and predation in the egg and larval stages? Neth J Sea Res 32:119-134

> Litvak MK, Leggett WC (1992) Age and size-selective predation on larval fishes: the bigger-is-better hypothesis revisited. Mar Ecol Prog Ser 81:13-24

MacArthur RH, Pianka ER (1966) On the optimal use of a patchy environment. Am Nat 100:603-609

Macpherson E, Raventos N (2005) Settlement patterns and post-settlement survival in two Mediterranean littoral fishes: influences of early-life traits and environmental variables. Mar Biol 148:167-177

> McCormick MI, Hoey AS (2004) Larval growth history determines juvenile growth and survival in a tropical marine fish. Oikos 106:225-242

Meekan MG, Fortier L (1996) Selection for fast growth during the larval life of Atlantic cod Gadus morhua on the Scotian Shelf. Mar Ecol Prog Ser 137:25-37

Meekan MG, Vigliola L, Hansen A, Doherty PJ, Halford A, Carleton JH (2006) Bigger is better: size-selective mortality throughout the life history of a fast-growing clupeid, Spratelloides gracilis. Mar Ecol Prog Ser 317:237-244

Miller TJ, Crowder LB, Rice JA, Marshall EA (1988) Larval size and recruitment mechanisms in fishes: toward a conceptual framework. Can J Fish Aquat Sci 45:1657-1668

> Nielsen R, Munk P (2004) Growth pattern and growth dependent mortality of larval and pelagic juvenile North Sea cod Gadus morhua. Mar Ecol Prog Ser 278:261-270

Paradis AR, Pepin P, Brown JA (1996) Vulnerability of fish eggs and larvae to predation: review of the influence of the relative size of prey and predator. Can J Fish Aquat Sci 53:1226-1235

$>$ Pepin P, Shears TH, Delafontaine Y (1992) Significance of body size to the interaction between a larval fish (Mallotus villosus) and a vertebrate predator (Gasterosteus aculeatus). Mar Ecol Prog Ser 81:1-12

Planes S, Romans P (2004) Evidence of genetic selection for growth in new recruits of a marine fish. Mol Ecol 13: 2049-2060

Rankin TL (2010) The effects of early life history on recruitment and early juvenile survival of a coral reef fish in the Florida Keys. PhD thesis, University of Miami

Rankin TL, Sponaugle S (2011) Temperature influences selective mortality during the early life stages of a coral reef fish. PLoS ONE 6:e16814

Richards WJ (2005) Guide to the early life history stages of fishes of the western central North Atlantic. CRC Press, Miami, FL
Robert D, Castonguay M, Fortier L (2007) Early growth and recruitment in Atlantic mackerel Scomber scombrus: discriminating the effects of fast growth and selection for fast growth. Mar Ecol Prog Ser 337:209-219

- Robert D, Takasuka A, Nakatsuka S, Kubota H, Oozeki Y, Nishida H, Fortier L (2010) Predation dynamics of mackerel on larval and juvenile anchovy: Is capture success linked to prey condition? Fish Sci 76:183-188

Robertson DR, Swearer SE, Kaufmann K, Brothers EB (1999) Settlement vs. environmental dynamics in a pelagicspawning reef fish at Caribbean Panama. Ecol Monogr 69:195-218

> Searcy S, Sponaugle S (2000) Variable larval growth in a coral reef fish. Mar Ecol Prog Ser 206:213-226

Searcy SP, Sponaugle S (2001) Selective mortality during the larval-juvenile transition in 2 coral reef fishes. Ecology 82:2452-2470

Shima JS, Swearer SE (2010) The legacy of dispersal: larval experience shapes persistence later in the life of a reef fish. J Anim Ecol 79:1308-1314

Shoji J, Tanaka M (2006) Growth-selective survival in piscivorous larvae of Japanese Spanish mackerel Scomberomorus niphonius: early selection and significance of ichthyoplankton prey supply. Mar Ecol Prog Ser 321: $245-254$

Sogard SM (1997) Size-selective mortality in the juvenile stage of teleost fishes: a review. Bull Mar Sci 60:1129-1157

Sponaugle S, Cowen RK (1997) Early life history traits and recruitment patterns of Caribbean wrasses (Labridae). Ecol Monogr 67:177-202

> Sponaugle S, Grorud-Colvert K (2006) Environmental variability, early life-history traits, and survival of new coral reef fish recruits. Integr Comp Biol 46:623-633

> Sponaugle S, Pinkard DR (2004) Impact of variable pelagic environments on natural larval growth and recruitment of the reef fish Thalassoma bifasciatum. J Fish Biol 64:34-54

Sponaugle S, Grorud-Colvert K, Pinkard D (2006) Temperature-mediated variation in early life history traits and recruitment success of the coral reef fish Thalassoma bifasciatum in the Florida Keys. Mar Ecol Prog Ser 308:1-15

- Sponaugle S, Llopiz J, Havel L, Rankin TL (2009) Spatial variation in larval growth and feeding success in a coral reef fish. Mar Ecol Prog Ser 383:239-249

> Swain DP (1992) Selective predation for vertebral phenotype in Gasterosteus aculeatus: reversal in the direction of selection at different larval sizes. Evolution 46:998-1013

- Takasuka A, Aoki I, Mitani I (2003) Evidence of growthselective predation on larval Japanese anchovy Engraulis japonicus in Sagami Bay. Mar Ecol Prog Ser 252:223-238

- Takasuka A, Oozeki Y, Kimura R, Kubota H, Aoki I (2004) Growth-selective predation hypothesis revisited for larval anchovy in offshore waters: cannibalism by juveniles versus predation by skipjack tunas. Mar Ecol Prog Ser 278: 297-302

Takasuka A, Aoki I, Oozeki Y (2007) Predator-specific growth-selective predation on larval Japanese anchovy Engraulis japonicus. Mar Ecol Prog Ser 350:99-107

> Tanaka Y, Satoh K, Iwahashi M, Yamada H (2006) Growthdependent recruitment of Pacific bluefin tuna Thunnus orientalis in the northwestern Pacific Ocean. Mar Ecol Prog Ser 319:225-235

Victor BC (1982) Daily otolith increments and recruitment in two coral-reef wrasses Thalassoma bifasciatum and Halichoeres bivittatus. Mar Biol 71:203-208

- Warner RR, Robertson DR (1978) Sexual patterns in the labroid fishes of the western Caribbean. I. The wrasses (Labridae). Smithson Contrib Zool 254:1-27 